\title{
Forum
}

doi:10.1017/S0373463312000501

\section{A Note on Helm Orders After the Coming of Steam}

\author{
Joghn Wilde Crosbie \\ (Barrister) \\ (E-mail: crossbee@eircom.net)
}

This note commences with the adoption by the newly invented steam ships, of the sailing ship's custom of referring helm orders to the direction in which the tiller was to be shifted. It records something of the early resiling of the non-English speaking nations from this counter intuitive custom and draws attention to the confusion which the lack of an international approach created, especially for a ship under pilotage. The note concludes with the international uniformity achieved for helm orders by Convention in 1929.

\section{KEY WORDS}
1. Words and phrases.
2. Shiphandling.
3. History.
4. Helm Orders.

Submitted: 10 August 2012. Accepted: 6 September 2012. First published online: 31 October 2012.

[The Captain] was thoughtful and grave - but the orders he gave

Were enough to bewilder a crew.

When he cried, "Steer to starboard, but keep her head larboard!"

What on earth was the helmsman to do?

Lewis Carroll, The Hunting of the Snark, $1^{\text {st }}$ April, 1876.

1. INTRODUCTION. The tiller protrudes from the rudder stock diametrically opposite to the rudder so that pushing against the tiller in one direction turns the ship's head in the other. A modern helmsman might find this effect counter-intuitive but, in the days of sail a helmsman, at sea from an early age and probably reared in small boats as a boy, would have considered the effect perfectly natural. Since the action of the helm had the effect of driving the ship's head in the opposite direction, the helmsman had to be very clear about the direction in which he was to turn the helm in response to an order, even though this might not be literally clear from the order itself.

In the days of sail, helm orders were given with reference to the moving of the tiller in relation to either the direction of the wind or the centre-line of the ship. Underway, the wind was an obvious reference point since each manoeuvre would be designed to 
bring the ship's heading more up into the wind or more downwind. Thus, the orders "Up with the helm!", "Bear up!", and, "Bear away!" were understood as instructing the helmsman to put his tiller a-weather, that is to say, to windward; and, the orders "Down with the helm!", "Luff your helm!", and, "Luff!" (or, "Luff up!") were understood as instructing the helmsman to put his tiller a-lee, that is to say to leeward. As an alternative to referring his orders to the direction of the wind, a pilot could give his helmsman orders with reference to the centreline of the ship by using the helm orders "Starboard!", "Port!", and, "Amidships!". Admiral W. H. Smith in his Sailor's Word Book cites the use of the order "Port the Helm!" as having been mentioned in an account of Arthur Pett's voyage to seek a North East passage in 1580 (Smith, 1867).

So, when steam ships were invented, they had a useful system of helm orders available to them which did not refer to the wind and which had been established for at least some 250 years. When Trinity House and the Admiralty published the 'Passing Rule' for steamers in 1840 it was expressed thus:

"When steam-vessels on different courses must unavoidably or necessarily cross so near, that by continuing their respective courses there would be a risk of coming in collision, each vessel shall put her helm to port, so as always to pass on the larboard side of the other."

2. THE FRENCH INFLUENCE. The 'Port Helm Rule' was refined in 1863 to apply to vessels meeting but its reference to the helm remained unchanged. In preparing the 1863 rules there was a considerable diplomatic effort to make them international. The meeting rule was expressed in English as:

"When two ships under steam are meeting end on, or nearly end on, so as to involve risk of collision, the helms of both shall be put to port, so that each may pass on the port side of the other."

This was translated by France as:

"Si deux navires sous vapeur se rencontrent courant l'un sur l'autre, directement ou à peu près et qu'il y ait risqué d'abordage, tous deux viennent sur tribord, pour passer à babord l'un de l'autre."

The Board of Trade in a letter to the Admiralty passed over this as a mere translation (Board of Trade, 1861). It was, of course, more than that since it indicated how the ship's head, rather than the helm, should be changed, even though the effect was the same. Subsequently, on 27th September 1874, France issued a decree directing that in order to lessen the number of collisions at sea, the signals babord (port) and tribord (starboard), on merchant ships should henceforth indicate the course to be taken, and not the movement made by the man at the helm (Lacon, 1874). Similar decrees were issued by Norway, Sweden and Austria to the effect that the motion of the pilot's arm, the direction of the ship's head and the word of command shall correspond (Lacon, 1878a). It is interesting to note from depositions made by the master and lookout of the French ocean liner Ville du Havre to the Receiver of Wreck in Cardiff on the $3^{\text {rd }}$ December 1873 that, prior to the French decree of 1874, the 
practice of French ships in relation to helm orders appears to have been the same as that of the English. The French captain deposed:

“My ship's helm having been put hard-a-starboard, but we could not clear, and the coming vessel struck me on my starboard quarter at an empty space, and cut me down below the water's edge, the water rushed in and my vessel went down in about 12 minutes". (Surmont, 1873)

Likewise, the lookout in the bows of the Ville du Havre deposed:

“After our trumpet sounded I saw our ship's head change to port, so that her helm must have been starboarded; and I believe that if the other vessel had starboarded we should have passed free, but I do not think that the other vessel (the Loch Earn) altered her course at all." (Enault, 1873)

3. THE FRANCONIA AND STRATHCLYDE COLLISION. The French decree was promulgated in the London Times and William Stirling Lacon wrote immediately to the Board of Trade pointing out that this was diametrically opposed to the English acceptance of the order (Lacon 1874). He particularly seems to have had in mind the case of a foreign ship in the charge of a pilot. In the course of the correspondence he wrote:

"From what I have now put before the Board of Trade, it is more than probable that the collision between the Franconia and the Strathclyde was caused by a mistake in the steering order. In broad daylight, at 4.15 p.m., the Franconia overtaking the Starthclyde, ran into and sank her, both ships steering almost the same course.

On board the Franconia were two pilots, a French pilot and an English Pilot.

From Grimsby to the South Sand Head Light the English pilot had charge of the ship, and his order 'port' implies, according to the custom and practice of England, that the ship's head shall go to the right. From Dungeness to Havre the French pilot has charge and his order 'port' implies, according to the decree of the French Government, that the ship shall go to the left. During the interregnum, namely, between the South Sand Head and Dungeness, the captain had charge when the accident happened.

There was no steering telegraph on board the Franconia and the man at the helm was at the stern, about 150 feet from the bridge. There was no evidence in what way the order was given, whether by word of mouth or by motion.

Before and during the trial at the Central Criminal Court, the attention of counsel of the Franconia was directed to this subject, but no question was asked to elucidate the subject, and a verdict of manslaughter was the result." (Lacon, 1878b)

In the course of his correspondence with the Board of Trade, Lacon also surmised that the collisions between the Alberta and the Mistletoe, and the Northfleet and the Murillo were caused by mistaken helm orders. However, there is nothing in the official reports (Parliamentary Paper, 1876, 1874) to suggest that the helmsman in either case misinterpreted the order given to him or that helm orders were at the root of these collisions.

4. THE GROSSER KÜRFURST AND KÖNIG WILHELM COLLISION. Though there appears to be no reported case at that time where a 
helmsman had interpreted an order to move the helm as an order to turn the bow of the ship, there was a real apprehension that this could happen.

It was in this climate that on the $31^{\text {st }}$ May 1878, in broad daylight and fine weather, a collision took place in the English Channel in which the German warship Grosser Kürfurst was sunk on her maiden voyage by her consort König Wilhelm. In that case, an order was given to starboard the helm and reverse the screw of the König Wilhelm but the ship unexpectedly responded by turning to starboard. The officers on the bridge were convinced that the men at the helm, of whom there were six, had responded to the order to "starboard!" by turning the wheel the wrong way and that it was this which brought the ship's head to starboard. This was the finding of the naval court. However, this finding was scotched by the scientific community in England which at that time was conducting experiments on the effects of transverse thrust on the rudder when the screw was reversed in an emergency. A committee of the British Association for the Advancement of Science expressed the view that all its experiments went to prove that with a reversed screw and a starboard helm, such a vessel as the König Wilhelm would have turned to starboard rather than to port; that this was what, according to all the evidence, did actually happen, and was the final cause of the catastrophe (Napier et al., circa 1878).

\section{THE RELATED PROBLEM OF THE RIGGING OF THE} WHEEL. The finding of the naval court in the König Wilhelm case was grist to the mill of the promoters of an internationally uniform system of helm orders. A pamphlet (Anonymous Pamphlet, circa 1878) was produced referring to a letter to the London Times from a Mr Hill of Glasgow, proposing that all verbal orders be done away with and a telegraph system of signals be substituted. The pamphleteer thought that this would not be suitable for small vessels and his proposal was that the words left and right be substituted for starboard and port, respectively, in helm orders. He thought that this would be more acceptable to seamen than interchanging the words 'Port' and 'Starboard' in helm orders. He seems to have been unaware that the French had effectively done this by decree in 1874 but instead he stated that the French had corrected the anomaly in most of their ships by reversing their wheels so that they were turned in the direction of the given order - that is to say when the word "Port!" was given, the wheel was turned to port, the rudder and the ship turning to starboard. The pamphleteer mentioned how a yacht called the Stella, built originally for an English nobleman and used by him was bought by a French gentleman and subsequently chartered by Mr MacIver, of Cunard's Co., who found that the Frenchman had reversed the wheel chains and helm indicator, so that when the word "Port!" was given the order was literally obeyed, instead of the contrary, as in a British ship. The pamphleteer suggested that Mr MacIver must have longed to retain the improvement. He also stated that the Italians had also tried to modify the evil by the same method but that he regarded this as a highly dangerous plan since it was not likely to become universal.

6. CONCLUSION. A unified system of commands to the helm was on the agenda (Protocol of Proceedings, 1890a) of the International Marine Conference held in Washington, D.C., in 1889. However, it seems that the subject was never discussed 
and nor was any recommendation made for their unification. However, in its model Rule of the Road, the Conference adopted the French wording for the meeting-end-on rule and prescribed that such vessels shall each alter course to starboard rather than prescribing that they put their helms a-port (Protocol of Proceedings, 1890b). The French wording of the meeting rule had already been adopted by Britain in 1880. This, of course, left the question of helm orders and the rigging of the wheel to the discretion of each nation. Finally, the matter was resolved at the International Convention for the Safety of Life at Sea held in London in 1929 and enacted in Britain by the Merchant Shipping (Safety and Load Lines Convention) Act, 1932, which made it illegal from $1^{\text {st }}$ January 1933 to give helm orders with reference to the tiller. Subsequently, Rule 32 of the 1954 Colregs provided:

"All orders to helmsmen shall be given in the following sense; right rudder or starboard to mean 'put the vessel's rudder to starboard'; left rudder or port to mean 'put the vessel's rudder to port'."

Unfortunately, this was not before an accident of the kind apprehended by William Stirling Lacon actually happened. According to the London Times $20^{\text {th }}$ February 1884, the French ship Indus was navigating the Thames in the charge of a pilot. The pilot gave the order "Tribord!" to which the French crew responded by turning the ship to starboard in accordance with the French usage. The pilot, of course, intended the ship to turn to port in accordance with the English custom. The error caused the Indus to allide with the training-ship Shaftesbury. The training-ship being on a mooring, admiralty lawyers describe such a collision as an allision. In subsequent proceedings, entitled London School Board v. Lardner, the pilot was held to blame (McGuffie, 1953).

\section{REFERENCES}

Anonymous Pamphlet. (circa 1878). Collisions Afloat-Causes which lead to them-The Terms Port and Starboard - What they mean - Ought they to be retained? Phillip, Son \& Nephew, Liverpool.

Board of Trade. (1861). Parliamentary Paper (1871) No. 240: Copy of certain correspondence between the Board of Trade and other Departments from 1850 to 1866 respecting the settlement of the Rule of the Road at Sea and the Lights to be carried by Ships, at page 52 .

Enault, A. (1873). UK Parliamentary Paper (1874) No. 167. Copy of correspondence between the Board of Trade and Foreign Office, and between Her Majesty's Government and the French Government, on the subject of the collision between the Loch Earn and the Ville du Havre at page 7.

Lacon, W.S. (1874). UK Parliamentary Paper (1878) No. 168. Copy of correspondence between Mr. W. Stirling Lacon and the Board of Trade on the subject of the Rule of the Road at Sea, at pages 14 and 15.

Lacon, W.S. (1878a). UK Parliamentary Paper (1878) No. 168. Copy of correspondence between Mr. W. Stirling Lacon and the Board of Trade on the subject of the Rule of the Road at Sea, at page 16.

Lacon, W.S. (1878b). UK Parliamentary Paper (1878) No. 168. Copy of correspondence between Mr. W. Stirling Lacon and the Board of Trade on the subject of the Rule of the Road at Sea at pages 16 and 17.

Napier, J. R., Thomson, Sir, W., Froude, W., Bottomley, J. T. and Reynolds, O. (1878). British Association for the Advancement of Science, Report of the Committee consisting of James R. Napier FRS, Sir W. Thomson FRS, W. Froude FRS, J. T. Bottomley and Osborne Reynolds FRS, Sec., appointed to investigate the effect of Propellers on the Steering of Vessels. http://www.biodiversitylibrary.org/page/ 29873091. Accessed August 2012.

McGuffie, K. C. (1953). Marsden's Collisions at Sea, Tenth Edition, at page 500, Stevens \& Sons, London. 
Parliamentary Paper. (1876). UK Parliamentary Paper (1876) No. 141. Papers relating to the Collision between Her Majesty's ship Alberta and the yacht Mistletoe.

Parliamentary Paper (1874). UK Parliamentary Paper (1874) No. C-917. Correspondence relating to the Murillo and the Northfleet.

Protocol of Proceedings. (1890a). Protocol of Proceedings of the International Marine Conference held in Washington D. C., 16 October to 31 December 1889, Volume II, at page vii, Government Printing Office, Washington.

Protocol of Proceedings. (1890b). Protocol of Proceedings of the International Marine Conference held in Washington D. C., 16 October to 31 December 1889, Volume II, at page 1372, Government Printing Office, Washington.

Smith, Admiral, W. H. (1867). The Sailor's Word-Book. Reprinted 2004 by Leonard G. Lee, Almonte, Ontario, at page 432.

Surmont, M. (1873). Parliamentary Paper (1874) No. 167. Copy of correspondence between the Board of Trade and Foreign Office, and between Her Majesty's Government and the French Government, on the subject of the collision between the Loch Earn and the Ville du Havre at pages 5 and 6. 